\title{
An Indian Perspective of Flood and Livestock
}

\author{
L. Arun ${ }^{1 *}$ and R. Senthilkumar ${ }^{2}$ \\ ${ }^{1}$ Department of Veterinary and Animal Husbandry Extension, CVAS, Mannuthy, Kerala \& \\ Assistant Professor, MSRS, Pottaneri, Tamil Nadu, India \\ ${ }^{2}$ Department of Veterinary and Animal Husbandry Extension, CVAS, Pookode, Kerala, India \\ *Corresponding author
}

\section{Keywords}

Flood disaster,

Effect on livestock, Flood management

Article Info

Accepted:

20 May 2020

Available Online:

10 June 2020

\section{A B S T R A C T}

Flood has been considered as one of the most recurring and frequent disasters in the world. Due to recurrent prevalence, the economic loss and life damage caused by the flood has put more burden on economy than any other natural disaster. India has continuously suffered by many flood events which claimed huge loss of life and economy. It has been found that the incidences of the flood are increasing very rapidly. Causes can be climate change, cloud bursting, tsunami, poor river management, silting etc. but devastation is increasing both in terms of lives and economies. In last decade, flood damaged more lives and economy than any other disasters. The damage caused by flood lasts several years from its advent. In the absence of an effective method to measure post impact of the flood, the assessment of loss and damaged is often not actual and far less than the actual cost. Disaster management in India has been well organised with many policies and programmes but administration and implementation of these programs demand more efficiency. The compensations and aids provided by the government and non-government organisations do not meet the cost of damages which brings higher economic burden to the people affected by these floods. It is well known that many developing countries, including India, are not always well prepared to deal with disasters. A lack of welldeveloped disaster management plans results in a severe loss of human life, animal life and property, which could be saved if the necessary mechanisms were in place. A lot need to be done to improve the situation, particularly in regard to livestock. In developing countries like India mitigation programmes should focus on strengthening global animal health services.

\section{Introduction}

India is highly vulnerable to natural disasters especially earthquakes, floods, drought, cyclones and landslides. Natural disasters affect human lives and livelihoods. India is ranked 11th among 15 countries facing "extreme risk" from natural disasters. Disaster is a sudden, calamitous event bringing great damage, loss, and destruction and devastation to life and property. The damage caused by disasters is immeasurable and varies with the geographical location, climate and the type of the earth surface/degree of vulnerability (Shankar, 2012). 
Disaster is defined as 'Catastrophic situation in which the normal pattern of life or ecosystem has been disrupted and extra ordinary emergency interventions are required to save and preserve lives and or the environment (Mathialagan and Rajkumar, 2012). Flood, an excess of water, can be caused by heavy rain fall followed by inadequate capacity of rivers to hold the water within their banks (Report, 2015). The 'great quantity of water' (in terms of river, or fluvial, flooding) is essentially caused by heavy rain that creates significant runoff into streams and generates a flow that exceeds the capacity of the river, causing water to flood out over the land (Adamson et al., 2003). According to FAO (2018), floods account for 17 per cent of total losses due to natural calamities across world and loss in livestock sector accounted for 34 per cent next to crop damage with 49 per cent.

\section{Occurrence of flood in India}

India is the worst flood-affected country in the world after Bangladesh and accounts for one fifth of the global death count due to floods (Bhatt and Ahmed, 2014). Around 40 million hectares of land in the country is affected by floods, according to Kausik and Sharma (2012) an average of 18.6 million hectares of land is affected annually. The annual average cropped area affected is approximately 3.7 million hectares (Roy et al., 2008). India has faced 649 disasters of various nature from 1915 to 2015. Out of these 649 events 302 disaster were caused by flood with on an average of 3 floods per year. This accounted approximately $47 \%$ of total disasters took place in India in the last 100 years.

Recently the state of Kerala was affected by floods during August 2018. As per United Nations the total loss was 26,720 crores with Agriculture, Fisheries and Livestock sector accounting for Rs. 7155 crores (Report, 2018).

\section{Perspective of animals' role in flood disaster}

Disasters affect the animals in the same way as human beings. Livestock population is the first to be affected in the precarious situation due to natural disaster like flood, drought, cyclone, volcanic eruption, earth quake, tsunami etc. (Heath et al., 1999). During any disaster for human beings, supplies of essential commodities are maintained even with great difficulty. In such situations saving of human life is considered on top priority basis and thus rescue, relief and rehabilitation is more directed for the people of affected areas with meagre attention to livestock and their sufferings (Pyne et al., 2009).

All animals are natural swimmers. Animals can forewarn, an incumbent disaster. Animals like the dogs are used for search and rescue operations. People escape holding on to animals during flash floods. During natural disasters, animals and animal driven carts are the available means of transport when no other transport is possible. In recovery phase animals are used for clearance of debris. During disaster the people lose their property and livelihood. Losses of crops, infrastructure or machinery take time to mitigate. Animals if salvaged can provide the community with food, energy, transport and the other utilities immediately (as long as they are healthy and cared for). Unlike standing crops or infrastructure, the animals can be salvaged and brought to safer places, where a disaster can be predicted. In transit camps or in rehabilitated dwellings too the animals can be utilised for milk, manure, transport, fuel (dung cakes). Animals are used for fetching water or for lifting water from the water sources, where machine or man power are not available or cannot be used. Even in their 
death animals serve the community; they provide some material gain through, their hide, bone, lard and carcass. Partially damaged crops \& grains unfit for human consumption can be gainfully used as animal feed (Ramakumar, 2012). In India majority of livestock enterprise is being managed by women. The women's regular cash income from sale of animal produces is utilised for household expenditure. Unexpected requirements of money, during flood like disaster is being met by livestock (Ramkumar et al., 2004)

In troubled times like floods some livestock activities may be salvaged to bring some relief to the farmers

1. Duck rearing and fish farming.

2. Extensive rearing of pigs. It also clears garbage and provide livelihood to economically weaker section and can be a cheap source of protein

3. Dogs (pets and community animals) play an important role in keeping creeping reptiles and straying wild animals at bay

4. People marooned during floods during winter have survived chilly nights taking refuge among herds of sheep and goats.

\section{Impact of flood disaster on livestock}

The main concerns for animals in disaster are zoonoses, animal bites, psychological impact on livestock owners and feeling of guilt, bereavement and anger due to loss, injury or death of the same, loss of livestock production, high mortality rates, increased predation, diseases during and after a disaster (Sen and Chander, 2002).

When animals are affected by disaster, the main problems are, as follows:

a) spoilage of food and/or the water supply

b) zoonoses c) animal bites

d) significant impact on public mental health due to the emotional involvement of the owners with the animals.

e) reduced dairy and livestock production, due to the scarcity of feed and water, high livestock mortality rates, etc.

f) damage to both domestic and wild animal species, due to lack of feed and water and the diseases which spread during and after a disaster.(Sen and Chander, 2003).

\section{Impact of flood on livestock economy}

Livestock play a very important role in the livelihoods of people in developing countries. Animals bring direct benefit as a source of food, as well as providing input to agriculture, and playing a role in income and savings. Beyond this, livestock bring in direct benefits through improved food security, nutrition, savings and insurance functions, cultural factors and more. These indirect benefits are often less obvious, but play a very significant role in development (Campbell and Knowles, 2011). Income is lost through death of animals, weight loss, reproductive losses and additional health care expenditures.

The impacts of flood on livestock sector are,

Loss of animal sourced foods.

Loss of draft power, increasing demand for human labour.

Loss of income generating opportunities.

Loss of culturally and socially important animals.

Reduced availability of draft power leading to increased demand for machinery and fuel.

Loss of savings and investment.

Loss of savings and investment.

Loss of manure.

\section{Impact of flood on animal health}

The detrimental impact of disasters on the health of a herd may reduce the value of the 
herd by between 30 per cent and 70 per cent. The most important causes of deterioration in animal (livestock and equines) health in disasters are,

Poor nutrition and subclinical disease

Malnutrition results in loss of body weight, energy and mineral imbalances,

Increased susceptibility to disease

Decreased reproductive efficiency

Fewer calves will be born and those that are born will be weaker

Flooding results in displacement of livestock and other animals and their owners.

Prolonged flooding of pastures kills vegetation, therefore reducing the nutritional value of pasture to grazing animals.

Flooding also removes organic matter from the soil which reduces the water-holding capacity of the soil.

Soils that have a low content of organic matter are more prone to droughts and landslides, and are less productive for plant growth.

The nutritional quality of grasslands that have been flooded is reduced because of decreased soil fertility, decreased organic matter in the soil,

Floods also deposit large amounts of debris in pastures which can be hazardous to grazing animals (for example, puncture wounds to the feet and skin).

Debris also reduces the effective grazing area of pastures. Debris can often be contaminated with hazardous chemicals that may affect the health of grazing animals, and may endanger humans who later consume contaminated meat or milk products.

Foot rot, FMD, blackleg and other contagious diseases such as internal and external parasites, respiratory infections and skin diseases.

Public health concerns may also arise due to outbreaks of zoonotic disease, including vector-borne diseases. hydatidosis and visceral larva migrans (Sen and Chander, 2003).

Preparation steps to be taken for mitigating for protecting livestock from flood

According to recommendations of Disaster District management plan, Shimla the following steps are to be followed for mitigating flood disaster for livestock.

Ensure isolation / separation of sick and healthy animals and prepare for arrangements for keeping, feeding and watering of animals suffering from contagious diseases.

Sensitize farmers/ owners for above problems.

Ensure separate transportation of animals suffering from contagious diseases.

Ensure proper disinfection of space, vehicle and manpower involved in transportation of sick/ infected and dead animal from contagious diseases.

Ensure fully functional mobile veterinary unit at disposal.

Prepare a database of veterinary hospitals/ clinics and agencies working for animal care.

Ensure availability of stocks of mineral and feed supplements, lifesaving drugs, electrolytes, vaccines, etc.

Ensure sensitization of farmers about protection of their feed and fodder prior to the onset of monsoon.

Ensure filling feed banks before the scarcity period.

Prepare for the feed of the poultry birds for drought situation.

Locate feed and fodder banks in view of submergence situation during the flood.

Identify source for procurement of fodder.

Identify safe locations for fodder depot and cattle camps within the district.

Ensure assured source of water or canals for drinking and growing fodder along with the above locations. 
Prepare for necessary arrangements of tatties, gunny bags and tarpaulin sheets to cover the sheds during heat and cold waves.

Ensure availability of sprinklers/ foggers in shed/camp during heat waves period.

Prepare for special care for productive, lactating and pregnant animals; also supplement them with additional concentrates and fodder.

Ensure proper administration of deworming and vaccinations for cattle, sheep and goats, pigs and other relevant measures for disease management.

Prepare for arrangements for transportation of critically injured livestock.

Identify space for burial of animals and ensure proper disposal of dead animals. (Report, 2017)

\section{Role for veterinarians in flood management}

For many years veterinarians have been the pioneers of animal health throughout the world. The veterinary profession has been responsible for the eradication of many diseases from many countries, the development of vaccines, disease surveillance and intervention programmes. Veterinarians have also responded to the needs of countries affected by geophysical disasters on many occasions.

The role of the veterinarian in the integrated programme of emergency management should be clear, and is no different from other aspects of veterinary disaster management: the care of animals is an effective method to provide better care for people. In the case of national disasters in developing countries, the attention to animal agriculture is an effective method to improve public health, the environment and the economy of the country (Moore et al., 1991).

\section{Way forward}

There is clearly an inadequate level of protection in our country against floods. Though non-structural measures improve the preparedness to floods and reduce losses, the necessity of structural measures would always remain to reduce the extent of physical damage caused by floods. It is thus necessary that resources are utilized efficiently. Apart from timely execution of new projects, it is as important to pay adequate attention to the maintenance of embankments and drainage channel. Poor maintenance is noted as a major weakness in the flood control system of the country. Maintenance of embankments, drainage channels, soil conservation and watershed management should be the responsibility of the beneficiaries, hence involvement of the community in the operation and maintenance of flood control measures through appropriate training and capacity building is necessary. People's participation in flood control through community management of flood protection structures and training in emergency action would go a long way in improving the preparedness to floods and reducing the damages caused by this natural phenomenon. On the other hand, there is enough evidence to suggest that exploitation of the environment can significantly impact the frequency and severity of natural disasters like floods. The loss of natural vegetation, particularly forests is a major cause of preventable natural disasters like floods. Thus along with investment in flood control, the government should ensure that environmental degradation is arrested and unplanned development in riverbanks checked through appropriate policies and awareness programmes. At the national level, flood control and management planning need to be integrated into development planning for the country (Gupta et al., 2003). 
For effective resilience of flood disaster in our country, the following activities should become order of the day (Swamy, 2010).

Community level disaster management activities with the help of Panchayati Raj institutions and NGOs (NonGovernmental Organizations) and programmes aimed at dissemination of information should be encouraged.

Decentralization of resources must be commensurate to the responsibilities, particularly at local level.

Integration of community-based disaster preparedness and mitigation plans into development plans prepared by communities and local governments and strengthening of local capacities and institutions have proved to be successful.

The emphasis should shift from mitigation to sustainable development.

The preparedness, response and rehabilitation mechanisms were primarily focused on human beings, whereas inadequate attention to livestock management is given. This situation leads to heavy loss, delayed and caused poor recovery from livestock related damages. The total loss due to flood related damages to livestock could be reduced with better preparedness, timely response and welldesigned rehabilitation efforts (Ganguliji and Chander, 2007). United Nations suggested the recovery vision for the Agriculture and allied sector affected by flood is to develop sustainable, responsible, integrated, inclusive, eco-friendly, and resilient agriculture (crop, livestock, fisheries/aquaculture) consistent with the policies of Government. In the short term, focus will be on restoration of the three subsectors, through the provision of inputs and restocking, replacement or repair of assets and infrastructure, reviving economic activity, strengthening farmers' capacity, and finding alternative income sources for the population (Report, 2018).
In conclusion, a flood disaster is not a physical happening, it is a social event. It is in one sense the manifestation of vulnerabilities of social system and prime attention should be given to doing something about such vulnerabilities. Thinking flood disaster as social phenomena allow them to be seen as something which can be reacted to as part of ongoing policies and programmes of national and social development-which could reduce societal vulnerabilities in the first place. Activities of development nature then can be seen as an integral part of disaster prevention and mitigation. It has been recognised that, while floods cannot be prevented, they can certainly be managed to minimise loss of lives, livelihood systems, property and damage to infrastructure and public utilities. Various measures for management of floods will ultimately lead to reduction in vulnerability to floods. Sustained efforts are required to address the problem to reduce the impact of floods in the short term and flood risk in the medium and the long term. So far the response to floods has been reactive in nature and has focused on rescue and relief in the post-flood situation. Preparatory, preventive and mitigate aspects of the flood management have not received due attention. In terms of recovery resource provisions, policy makers should place more emphasis on proactive measures (structural and nonstructural mitigation measures) rather than reactive (response and recovery) that is usually done after the disaster strikes, and this would save lives, cost of damages to the respondent and government expenditure on recovery resources. To minimize flood damages, community members may be made a key stakeholder in devising strategies for flood risk management.

\section{References}

Adamson, M., Dipbs, M. and Miei, C., 2003. 
Floods causes, management and relief. Available:

http://citeseerx.ist.psu.edu/viewdoc/dow nload?doi=10.1.1.555.1978\&rep=rep1\& type $=$ pdf [29 May 2020]

Bhatt, S. and Ahmed, S,A. 2014. Morphometric analysis to determine floods in the Upper Krishna basin using Cartosat DEM. Geocarto International, 29(8):878-894.

Campbell, R. and Knowles, T. 2011. The economic impacts of losing livestock in a disaster, a report for the World Society for the Protection of Animals (WSPA).

Available:

http://www.gndr.org/images/newsite/Le arning/Animal-Protection/EcolargeLivestockDisasterEconomics-Final.pdf[ 25 May 2020]

FAO., IFAD., UNICEF., WFP and WHO. 2018. The State of Food Security and Nutrition in the World 2018. Building climate resilience for food security and nutrition. Rome, FAO.

Gangulji, D. and Chander, M. 2007. Impact of natural disasters on livestock farmers: the case of Orissa supercyclone of 1999 in India. The Indian Journal of Animal Sciences, 6:77.

Gupta, S., Javed, A. and Datt, D. 2003. Economics of flood protection in India. Flood Problem and Management in South Asia, 199-210.

Heath, S.E., Kenyon, S.J. and Zepeda Sein, C.A. 1999. Emergency management of disasters involving livestock in developing countries. Scientific and Technical Review of the Office International des Epizooties, 18 : 256271.

Kaushik, A.D. and Sharma, V.K., 2012. Flood Management in India. Indian Journal of Public Administration, 58(1):.119-136.

Mathialagan, P. and Rajkumar, N.V. (2015) Animal Disaster Management (ADM) Models for Tamil Nadu - An analysis [article] In: Compendium, International Symposium on Animals in Disaster: 26th to 27th September, 2018, Chennai, Tamil Nadu Veterinary and Animal Sciences University. Pp. 255-265.

Moore, R.M., Kaczmarek, R.G. and Davis, Y.M. 1991. Natural disasters: The role of the veterinarian. Pre hospital and Disaster Medicine, 6(2): 265-270.

Pyne, S.K. and Samanta, G. 2009. Livestock management at different levels of disaster-strategy and execution. Indian Journal of Animal Research, 43(2): 99102.

Ramakumar, V (2012). Role of Livestock and other animals in Disaster Management. Available:

https://www.vethelplineindia.co.in/roleof-live-stock-and-other-animals-indisaster-management/[ 26 May 2020]

Ramkumar, S., Rao, S.V.N. and Waldie, K. 2004. Dairy cattle rearing by landless rural women in Pondicherry: a path to empowerment. Indian Journal of Gender Studies, 11(2): 205-222.

Report, 2015. [book on-line.] National Institute of Disaster Management. Available: http://www.nidm.gov.in/ [24 May 2020]

Report, 2017. [book on-line]. District Disaster Management Plan, Shimla. Available: https://cdn.s3waas.gov.in/s3b534ba682 36ba543ae44b22bd110a1d6/uploads/20 18/07/2018071721.pdf [25 May 2020]

Report.2018. [book on-line.]United Nations., Asian Development Bank., Govt. of Kerala., The World Bank and European Union. Kerala Post Disaster Needs Assessment Floods and Landslides August 2018. Available: https://www.undp.org/content/undp/en/ home/librarypage/crisis-prevention-andrecovery/post-disaster-needsassessment---kerala.html [25 May 2020]

Roy, P.S., Bhanumurthy, V., Murthy, C.S., Kiran Chand, T. 2008. Space for 
disaster management: lessons and perspectives. Journal of South Asia Disaster Studies. 1:157-177.

Sen, A. and Chander, M. 2003. Disaster management in India: the case of livestock and poultry. Scientific and Technical Review of the Office International des Epizooties, 22(3): 915-930.

Sen, A. and Chander, M. 2002. Disaster management in India: The case of livestock", in proc. 28th Indian Veterinary Conference of Indian Veterinary Association and National Seminar on "Biological Threats and Disaster Management - role of Veterinarians". PAU, Ludhiana, 9-11 August, 2002, 41-56.

Shankar, G. 2012. Disaster Management. Journal of Disaster Advances. 5: 974.

Swamy, R.N. 2010. Disaster Management in India. Open learning, 36.

\section{How to cite this article:}

Arun, L. and Senthilkumar, R. 2020. An Indian Perspective of Flood and Livestock. Int.J.Curr.Microbiol.App.Sci. 9(06): 2495-2502. doi: https://doi.org/10.20546/ijcmas.2020.906.303 